\title{
POKRAJINSKOEKOLOŠKE ENOTE V PLANICI
}

\author{
Franc Lovrenčak \\ Dr., Oddelek za geografijo, Filozofska fakulteta Univerze v Ljubljani, \\ Aškerčeva 2, 1000 Ljubljana, Slovenija. \\ e-mail: franc.lovrencak@ff.uni-lj.si
}

\begin{abstract}
Izvleček
Planica je dolga ledeniška dolina na severni strani Julijskih Alp. V pleistocenu jo je v zgornjem in srednjem delu preoblikoval obsežen ledenik izpod Jalovca $(2645 \mathrm{~m}) \mathrm{v}$ značilno ledeniško dolino. Po umiku ledenika so na vznožju pobočij nastala melišča, ki pa še vedno nastajajo. Z melišči se menjavajo vršaji. Na dnu doline je v njenem osrednjem delu morena, ki se začne na južnem delu doline in sega $v$ njen severni del. Na različno starih reliefnih oblikah so nastale različno stare prsti. Vse to je povzročilo razlike tudi v vegetaciji. Glede na razlike $\mathrm{v}$ reliefnih oblikah, prsti in vegetaciji je mogoče $\mathrm{v}$ Planici razlikovati štiri osnovne pokrajinskoekološke enote. Za vsako od njih je značilno: kamnina, relief, prst in rastlinstvo.
\end{abstract}

Ključne besede: Planica, pokrajinskoekološke enote, relief, matična podlaga, prst, rastlinstvo.

\section{THE LANDSCAPE-ECOLOGICAL UNITS IN THE PLANICA VALLEY, IN THE JULIAN ALPS}

\begin{abstract}
Planica is a long glacial valley, situated on the northern side of the Julian Alps. During the Pleistocen its upper and middle part were transformed by a vast glacier, coming from under the Jalovec $(2645 \mathrm{~m})$ and thus turned it into a typical U-sloped glacial valley. After the withdrawal of the glacier screes appeared. There lies a moraine in the middle part of the Planica valley, beginning in the southern part and extending to the north. Since such landforms, which serve as a basis for the development of soils, are of different age, the soils naturally belong to different periods in time, too.All that has contributed to the diversity of vegetation. Regarding the variety of land-forms, soils and vegetation, one can distinguish four main landscape-ecologic units in Planica, consisting of typical landforms, soils and vegetation.
\end{abstract}

Key words: Planica, landscape-ecological units, landforms, bedrock, soil, vegetation. 